\begin{tabular}{ll}
\hline 臨 & 床 \\
\hline
\end{tabular}

\title{
人工内耳における正円空電気刺激検査
}

\author{
过一純・森福 孝之・中村一 \\ 伊藤 壽一・本庄縓
}

\section{Round Window and Promontory Tests for Cochlear Implant}

\author{
Jun Tsuji, Takayuki Morifuku, Hajime Nakamura, \\ Juichi Ito and Iwao Honjo
}

(Kyoto University)

\begin{abstract}
Round window tests were clinically examined and compared with promontory tests in 6 cochlear implant candidates. The round window test results showed lower stimulating thresholds and wider dynamic ranges than the promontory tests. To test the promontory tests in different stimulating positions and to compare them more precisely with round window tests, the electrical auditory brainstem response (E-ABR) was examined in guinea pigs receiving Kanamycin (KM) injections $(40 \mathrm{mg} / \mathrm{kg} /$ day for 30 days) that had lost their responses to the auditory brainstem response. The lowest E-ABR stimulating threshold in guinea pigs was recorded at the round window.
\end{abstract}

Key words: round window test, promontory test, cochlear implant

はじめに

人工内耳の手術適応を決める際に promontory test は，不可欠なむのとされている ${ }^{12)}$. 本法は経鼓膜的に電極を蝸牛岬角上に置き，そ の電極に通電し，音として感じ得るかどうかに よって聴神経の生存を確認するあのである。し かしpromontory testでは, 電極の位置により刺 激部位が毎回必ずしも一定せず，反応のばらつ きが認められるため, 我々は人工内耳手術適応 決定に際して, 通常の promontory test に加え, 局麻下に鼓室を開放し正円空に直接電極を置い て電気刺激する正円空電気刺激検査 (round window test) を行っている3 . 今回我々は，人 工内耳手術候補症例に対し, promontory test と round window test を施行し，両者の反応を比 較した.さらに promontory test の刺激部位に よる閾值の違い，抒よび round window testと の比較を詳しく調べるため, カナマイシン $(\mathrm{KM})$ を投与し，聴性脳幹反応(ABR)無反応となった モルモットを用い蝸牛岬角及び正円空を電気刺 激 Lelectrical auditory brainstem response (EABR) を記録した。

\section{方法}

臨床例：言語獲得後, 両側壟となった人工内 耳手術候補者 6 例で，醕の原因は頭部外傷 1 例, 耳硬化症 2 例, ストレプトマイシン難聴 2 例, 突発性難聴 1 例であった.

promontory test は，鼓膜を局所麻酔し針電 
極を経鼓膜的に岬角にあて，交流パルス電流で 刺激し，患者が音として感知し得る最小電流を $\mathrm{T}$ (threshold) level，苦痛を伴わずに音を感じ 得る最大電流をC (comfortable) level とし測定 した. round window test は局麻下に鼓室試験開 放を行い，正円空に直接刺激電極をおき，promontory test の時と同様の刺激で T-level およ び C-level を測定した.

動物実験：実験動物は，体重約 $250 \mathrm{~g} \sim 450 \mathrm{~g}$ の白色モルモットを使用した. $400 \mathrm{mg} / \mathrm{kg}$ の $\mathrm{KM}$ 連日筋肉内投与を 30 日間行い，プライエ ル耳介反射の消失を確認した。 このモルモット にネンブタール $(40 \mathrm{mg} / \mathrm{kg})$ を腹腔内注入した 後, 先ず ABR (100 dBSPL, 1 msec click 1 波 長)の消失を確認し，次に以下の方法で $\mathrm{E}$ $\mathrm{ABR}$ を測定した。中耳骨胞を開放し，蝸牛抒 よび正円空を単極の針電極で刺激し E-ABR を測定した。刺激電流は図 1 のように，持続時 間 $200 \mu \sec$ の 2 相性矩形波(A波) 100 回及びそ の逆相 (B波) 刺激100回を $100 \mathrm{msec}$ の interval で行い，反応波を加算平均した. $\mathrm{ABR}$ 执よび $\mathrm{E}-\mathrm{ABR}$ の検知電極は，陽極を耳介後下部，陰 極を頭頂部，不関電極を鼻尖部に置いた。

\section{結 果}

臨床例：表 1 に，同一患者における promontory test の刺激部位の違いによる閾值の差を示 した. position 1 は promontory のほぼ中央部
で, position2 は, round window の近傍であ る. position 1 に比べ, position 2 では C-level が低い。とのように promontory test では刺激 部位の違いによる閾值の違いが見られた。

図 2 は promontory test 及び round window test を行った 6 例に於ける，それぞれの test の 閾值を示したものである。ほぼ全例で round window test が promontory test に比べて Tlevel が低く，また T-level と C-level の間の dynamic range 屯広くなっている。また症例 1 の $200,400 \mathrm{~Hz}$, 症例 5 の $1600 \mathrm{~Hz}$ のように promontory test で反応がなくても round window test で反応がみられる場合があった。

動物実験：図 3 に KM 投与モルモットの $\mathrm{E}$ $\mathrm{ABR}$ 波形の 1 例を示す。刺激電流 $1 \mathrm{~mA}$ から $0.4 \mathrm{~mA}$ まで反応波形が得られている．とのよ

表 1 promontory test での電極の位置による差 （臨床例）

\begin{tabular}{c|c|c|c|c}
\hline \multirow{2}{*}{} & \multicolumn{2}{|c|}{$\begin{array}{c}\text { position 1 } \\
\text { (promontory 中央) }\end{array}$} & \multicolumn{2}{|c}{$\begin{array}{c}\text { position 2 } \\
\text { (round window 近く) }\end{array}$} \\
\cline { 2 - 5 } & T-level & C-level & T-level & C-level \\
\hline $50 \mathrm{~Hz}$ & 35 & $>500$ & 40 & $>500$ \\
100 & 90 & $>500$ & 41 & $>500$ \\
200 & 160 & $>500$ & 70 & $>500$ \\
400 & 280 & $>500$ & 81 & $>500$ \\
800 & 340 & $>500$ & 114 & $>500$ \\
1600 & 470 & $>500$ & 162 & $>500$
\end{tabular}

$(\mu \mathrm{A})$
1) 刺激波形

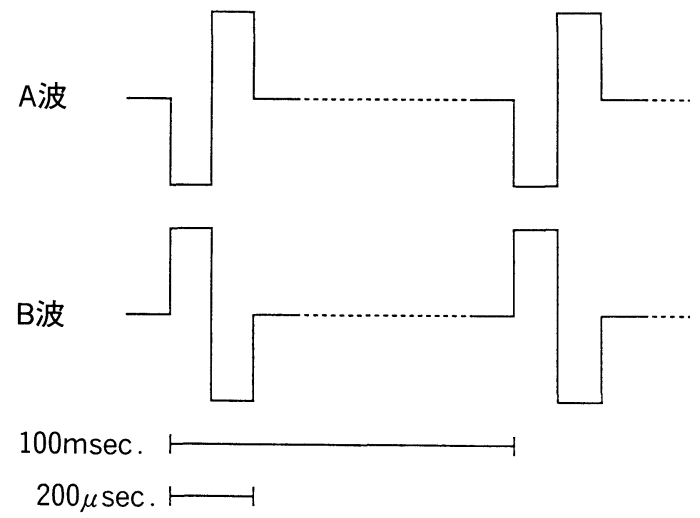

2) 加算回数
A波：100回
B波：100回

3）刺激電極:

蝸牛および正円空

\section{対電極：}

対側耳介

図 1 E-ABR 刺激電流 


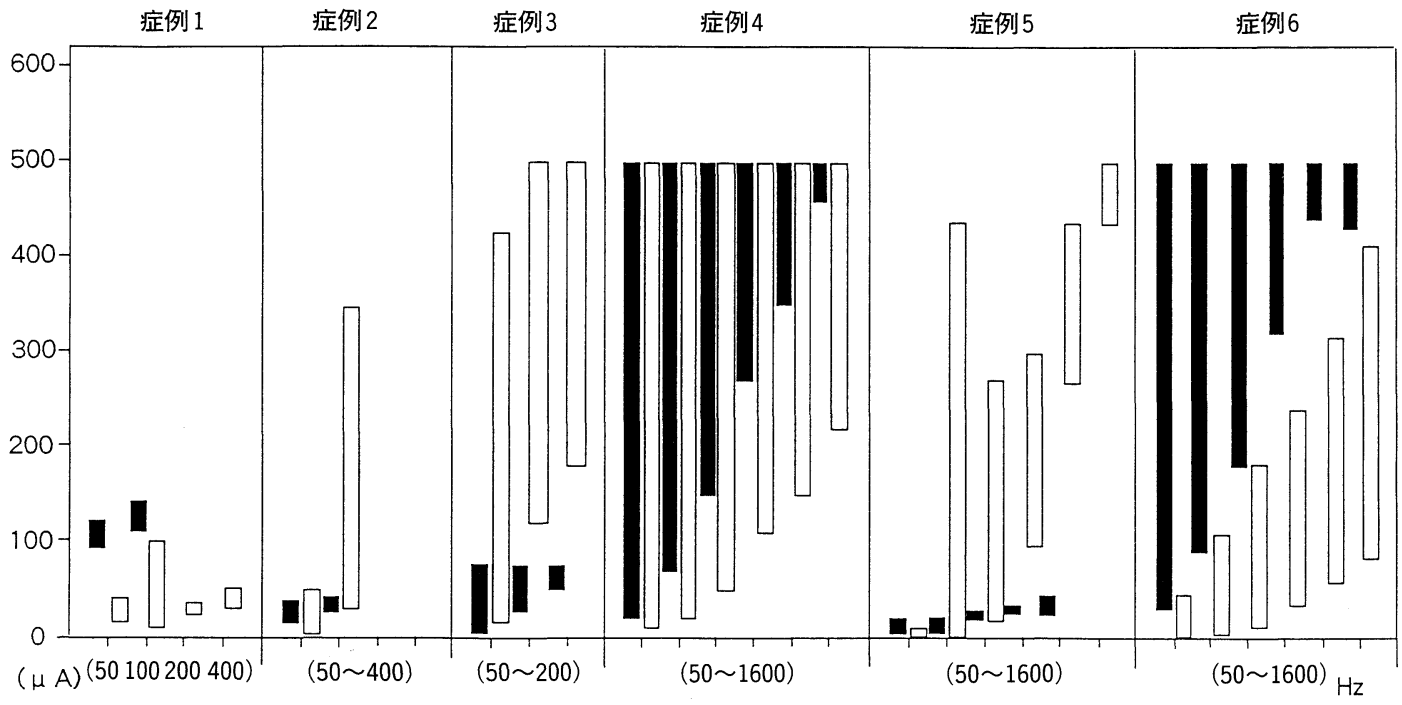

promontory test $\square$ round window test

図 2 promontory test と round window test $\sigma$ 比較

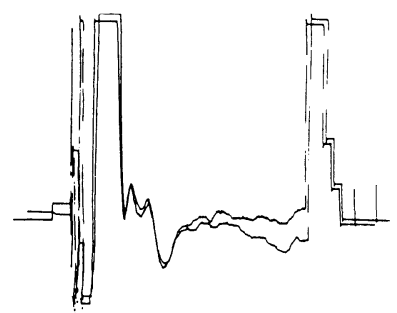

1. $0 \mathrm{~mA}$

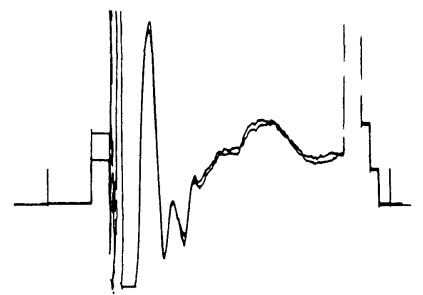

$0.4 \mathrm{~mA}$

$2.5 \mu \mathrm{V}$

$2 \mathrm{~ms}$

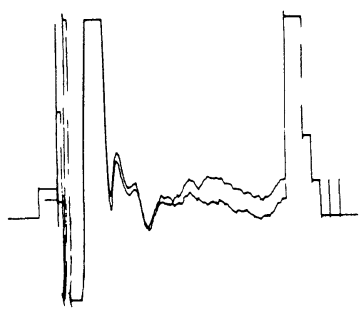

$0.8 \mathrm{~mA}$

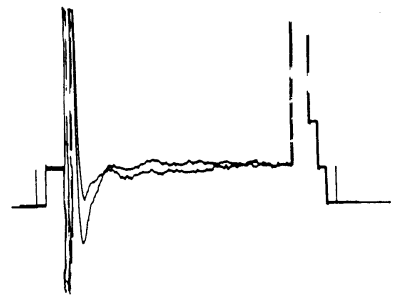

$0.3 \mathrm{~mA}$

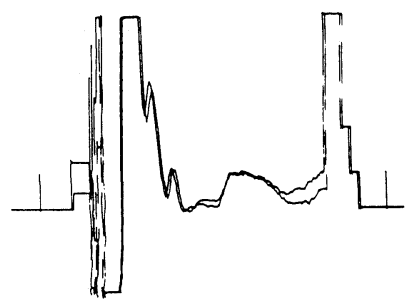

$0.6 \mathrm{~mA}$

図 $3 \mathrm{E}-\mathrm{ABR}$ 波形 
表 $2 \mathrm{KM}$ 投与モルモットの $\mathrm{E}-\mathrm{ABR}$ 閾值

\begin{tabular}{c|c|c|c|c}
\hline & case 1 & case 2 & case 3 & case 4 \\
\hline $\begin{array}{c}\text { basal turn } \\
\text { 遠 位 }\end{array}$ & 0.6 & 0.8 & 0.8 & 0.6 \\
\hline $\begin{array}{c}\text { basal turn } \\
\text { 近 位 }\end{array}$ & 0.5 & 0.6 & 0.5 & 0.4 \\
\hline 正 円 空 & 0.3 & 0.4 & 0.3 & 0.3
\end{tabular}

$(\mu \mathrm{A})$

うな波形を観測することで電流刺激に対する聴 覚反応の閾值を蝸牛および正円空で計測した。

表 2 はその結果である。全例に扮いて，正円 空での電流刺激閾值が最も低く，また蝸牛骨壁 上での刺激でも基底回転の正円空側の方が刺激 閾值が低いことが判った。

\section{考察}

同一患者の promontory test で，刺激場所の 違いによって閾值に差がみられた。刺激電流が 聴神経に伝わるのは中耳粘膜から正円㤵を介し てと思われるが，中耳粘膜や骨組織の状態の差 によって電流の伝わり方が影響をうけると考え られる，表1のような刺激位置による閾值の違 いは，promotory test が必ずしむ正確なもので はないととを示している.

round window test は promotory test の際の 刺激位置による差を避け，内耳に最も近い場所 で刺激を行うために，正円空を直接刺激する屯 のであるが，ほぼ全例で promontory test と比 べて刺激閾值が低く, dynamic range 屯広くな っていた。 また promontory test で一部反応が 無くても round window test では反応がみられ る症例屯あった。このように round window test は promotory test より鋭敏な検査であると 考えられた。

この結果を詳しく検討するため, KM 投与に よって ABR 無反応となったモルモットの蝸牛 及び正円空を電気刺激し $\mathrm{E}-\mathrm{ABR}$ をとり，各々 の刺激閾値を比較した。その結果，全例におい
て, 蝸牛の basal turn の各部に比して round window での電流刺激が最も閾值が低かった。 このようにモルモットにおいても正円空の直接 電気刺激が，電流刺激に対する内耳の反応性を 最む良く反映すると考えられた。

以上の臨床例及び，動物実験から round window test は promontory test より 鋭敏な検 査であり，聴神経の電流刺激に対する反応性を より直接的に反映するものと思われる.

また，通常の promontory test で反応が不良 な場合や無反応の場合でも，round window test により聴神経の生存状態を判定し，手術の適応 決定を行なうことが妥当と思われた。

\section{まとめ}

1) round window test $は$ promontory test に比べて，臨床的に低い閾值と広い dynamic range が得られた。

2) $\mathrm{KM}$ 投与モルモットの $\mathrm{E}-\mathrm{ABR}$ で，正 円空の直接電気刺激が蝸牛骨壁の他の部位の刺 激に比べて最も反応が良好であった。

3 ) round window test は, 人工内耳埋め込 み手術の適応決定に際し，有用な検査と思われ た。

\section{文献}

1) Clark GM, Blamey PJ, Brown AM, et al : The University of Merlbourne-Nucleus multi-electrode cochlear implant. Advance in oto-rhinolaryngology vol 38. pp 85〜92, Karger, Basel, 1987.

2) Rothera M, Conway M, Brightwell A, et al : Evaluation of patient for cochlear implant by promontory stimulation. Br J Audiol 20:25 28, 1986.

3 ）伊藤壽一, 中村 一, 本庄 簏, 他 : 人工内耳の 段階手術. 耳鼻臨床 $82 ： 1239 \sim 1241 ， 1989$.

$$
\left(\begin{array}{l}
\text { 原稿受付 : 平成元年 } 9 \text { 月 } 25 \text { 日 } \\
\text { 原稿採択 : 平成 } 2 \text { 年 } 8 \text { 月 } 3 \text { 日 } \\
\text { 急載 } \\
\text { 刷請求先 : 过 純 } \\
\text { 京都大学医学部耳鼻咽喉科学教室 }
\end{array}\right)
$$

